\title{
Quercetin-induced inhibition and synergistic activity with cisplatin - a chemotherapeutic strategy for nasopharyngeal carcinoma cells
}

\author{
Maelinda Daker, Munirah Ahmad and Alan SB Khoo*
}

\begin{abstract}
Background: Nasopharyngeal carcinoma (NPC) is a unique tumour of epithelial origin with a distinct geographical distribution, genetic predisposition and environmental as well as dietary influence as aetiological factors. Standard NPC treatment regimes, such as radiotherapy and concurrent chemotherapy with cytotoxic drugs, can produce undesirable complications often associated with significant toxicity. Here, we report the effects of a widely distributed flavonoid, quercetin, on cell proliferation, apoptosis and cell cycle arrest. The effects of combining quercetin and cisplatin on human NPC cells were explored.
\end{abstract}

Methods: Cell proliferation was monitored by the dynamic, impedance-based cell analyzer (xCELLigence system) and the MTS assay. Ki67 proliferation antigen and fatty acid synthase (FASN) level was examined by Western blotting. Flow cytometry was also carried out to study the effects of quercetin on cell cycle and apoptosis status.

Results: At $100 \mu \mathrm{M}$, quercetin inhibited cell proliferation and decreased expression of FASN and Ki67 antigen. Cell cycle analysis revealed a substantial increase in the proportion of cells in the G2/M phase. We also demonstrated the enhanced cytotoxic effects of quercetin treatment in concomitant with the chemotherapeutic drug, cisplatin, in cultured NPC cells. The combination index (Cl) value of quercetin-cisplatin combination was $<1$, indicating synergism.

Conclusions: Our study showed that quercetin exhibited synergistic effects with cisplatin against NPC cells. Dosereduction index (DRI) values $>1$ implied the possibility of reducing the cisplatin dosage required to treat NPC, with the addition of quercetin. In turn, this could reduce the risk of cisplatin-associated toxicity. The potential of combining quercetin with cisplatin as a chemotherapeutic strategy for treatment of NPC should be explored further.

Keywords: Cell proliferation, Chemotherapy, Cisplatin, Nasopharyngeal carcinoma, Quercetin, Synergism

\section{Introduction}

Nasopharyngeal carcinoma (NPC), a disease with distinct ethnic and geographic distribution, is common in Southern China, North Africa and South East Asia including Malaysia [1]. Approximately 95\% of NPC cases [2] are strongly associated with latent infection of the Epstein-Barr virus (EBV).

Radiotherapy is the primary modality of treatment for NPC. In addition, concurrent chemotherapy with cisplatin and 5-fluorouracil is used. High survival rates are

\footnotetext{
* Correspondence: alankhoo@imr.gov.my
Molecular Pathology Unit, Institute for Medical Research, Jalan Pahang, Kuala

* Correspondence: alankhoo@imr.gov.my Lumpur 50588, Malaysia
}

reported for stage 1 and stage 2 diseases [2]. Unfortunately, even with combined radiation and chemotherapy treatment, the rate of disease relapse is as high as $82 \%$ [2] and patients with locoregionally advanced disease, which most patients present, will eventually fail with distant metastases [3]. Improving outcomes are not without side-effects and are often linked to toxicity [4]. In addition, drug resistance may hamper the efficacy of these anticancer drugs. Potential NPC chemotherapy via natural product administration may circumvent some of these chemical- and radiation-associated toxicities.

Quercetin (3,3,4,5,7-pentahydroxyflavone) is a polyphenolic flavonoid widely distributed in fruits and vegetables, including apple, blueberries, broccoli, grape, leek, 
lettuce, onion and tomato. Being in a class of integral flavonoids common in our diet, it should exert low toxicity [5]. Quercetin may act on multiple targets. The mechanisms responsible for the cancer-preventive effects of quercetin and other flavonoids are attributed to their anti-oxidative activity, inhibition of enzymes that activate carcinogens, modification of signal transduction pathways, and interactions with receptors and/or proteins, described in [6]. Quercetin was reported to inhibit enzymatic activity of fatty acid synthase (FASN) and arrest cell growth [7]. It was shown to effectively inhibit growth in NPC HEN1 cells [8], human head and neck squamous cell carcinoma [9], human leukemic T-cells [10], human gastric cancer HGC-27 cells [11] and modulates Caco-2 human colorectal adenocarcinoma cell proliferation in a biphasic way [12]. To overcome obstacles associated with the limitation of cancer chemotherapy, possible biochemical modulation of anticancer drugs in concomitant with other agents, have been evaluated [13]. Here, we report the effects of quercetin treatment alone and in combination with cisplatin, in a set of EBV-negative and EBV-positive NPC cell line.

\section{Results}

Dynamic monitoring of quercetin-treated cells

To determine the effect of quercetin on NPC cells, the $\mathrm{xCELLigence} \mathrm{system,} \mathrm{a} \mathrm{real-time} \mathrm{cell} \mathrm{proliferation,} \mathrm{viabil-}$ ity and cytotoxicity analyzer, was conducted. The assay involved exposing cells to $0-100 \mu \mathrm{M}$ quercetin. The cell-electrode impedance response generated from the interaction of cells with the electronic biosensors was used to derive the cell index, representing growth over time (Figure 1a). At $100 \mu \mathrm{M}$, quercetin inhibited NPC cell proliferation. Essentially similar results were obtained when the experiment was repeated using C666-1 cells (Figure 1b), proving the consistent effect of quercetin in EBV-negative and EBV-positive NPC cells.
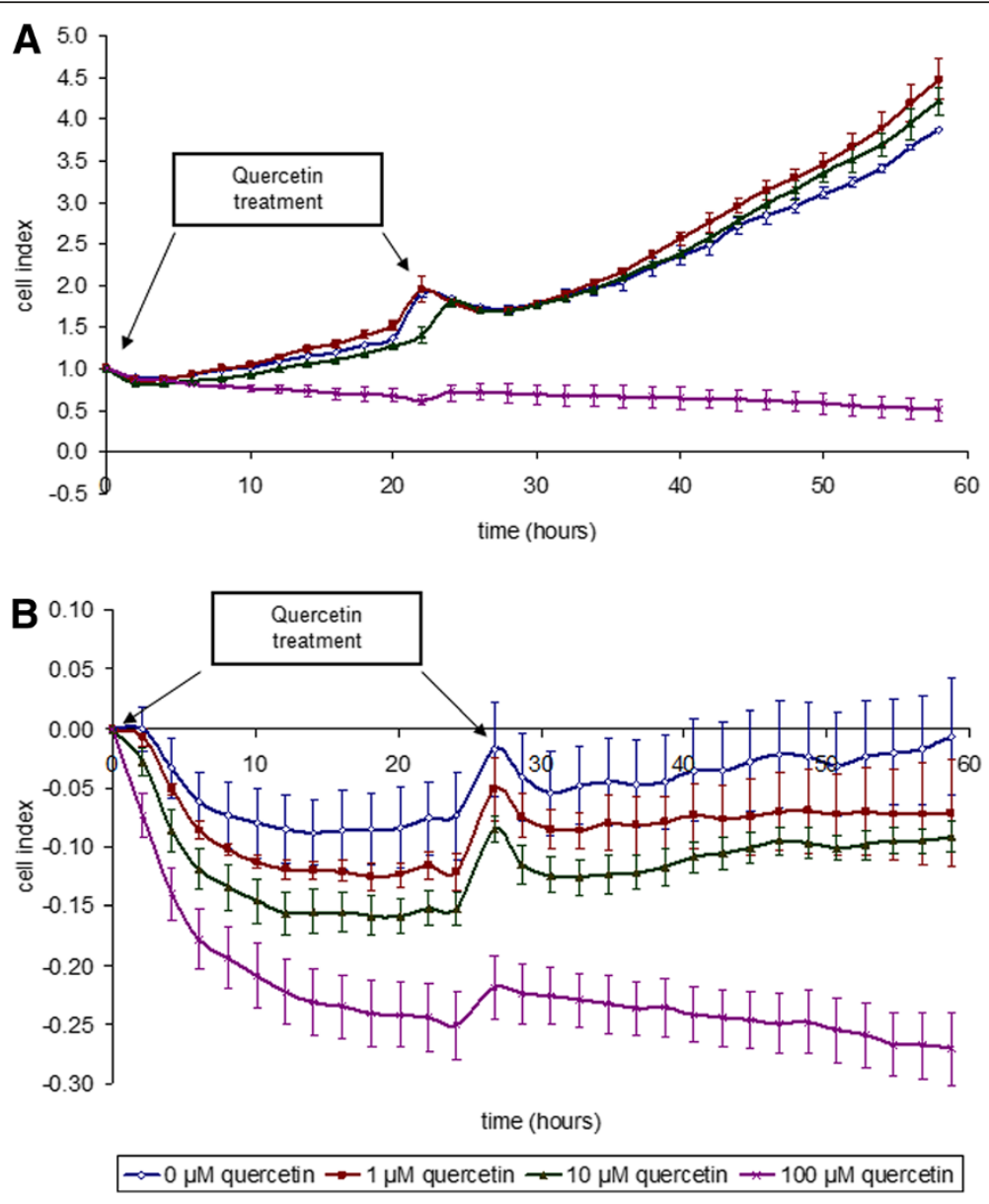

Figure 1 Growth curves generated from acquired cell index depicting the effect of quercetin on (A) HK1 and (B) C666-1 cell proliferation. $100 \mu \mathrm{M}$ quercetin inhibited HK1 and C666-1 cell proliferation. The graph shown is a representative of triplicate experiments. 


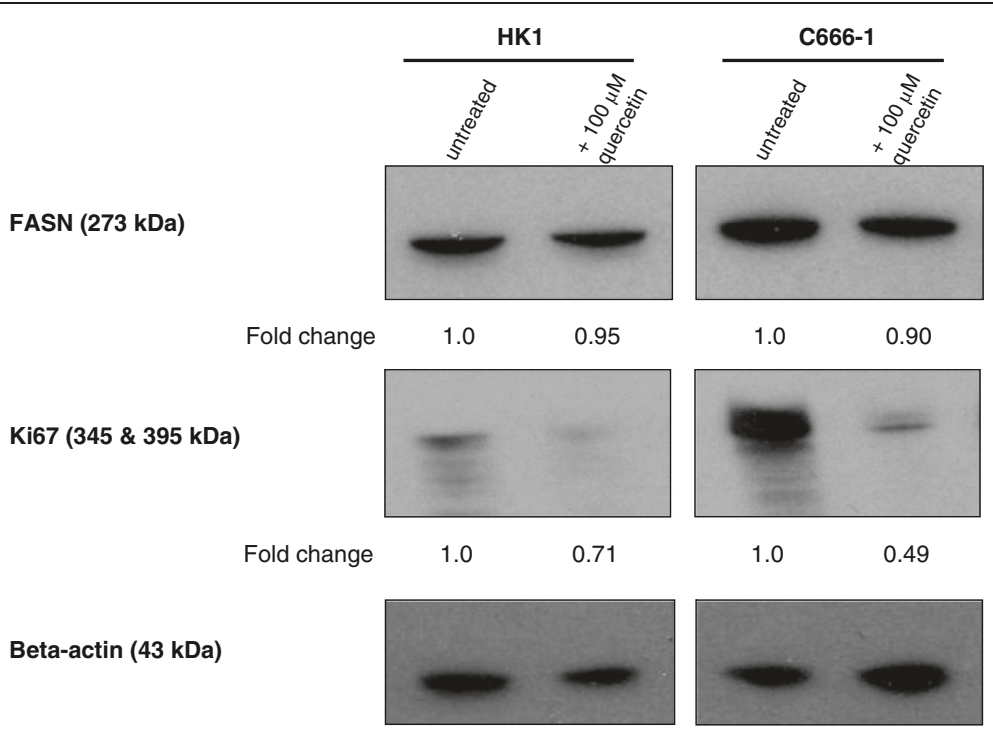

Figure 2 Immunoblot for FASN and Ki67 24 hours after quercetin treatment. HK1 and C666-1 cells treated with quercetin expressed lower amount of FASN and Ki67 compared to untreated cells. Detection of $\beta$-actin served as a loading control. The experiment was repeated twice and consistent results were obtained. A representative result is shown.

Because human cancer cells have elevated levels of fatty acid synthase (FASN) and undergo exacerbated endogenous fatty acid synthesis to maintain a constant supply of lipids and lipids precursors for membrane production in a highly-proliferating population [14] and the Ki67 antigen is a cell proliferation marker, quantification of FASN and Ki67 in HK1 cells was performed. Since there is no standard method for interpreting Ki67 immunostaining (for example, area of view selected for scoring and/or number of cells for scoring) and various methods may account for the diverse results reported, we attempted to quantify, via Western blotting, FASN and Ki67 antigen expression to assess their link to proliferative activity. We showed that FASN expression was marginally lowered by quercetin (Figure 2) following quercetin-induced cell proliferation inhibition. Simultaneously, the downregulation of Ki-67 expression was clearly observed (Figure 2). The C666-1 cell line was included for comparison. This was in agreement with Figure 1 which revealed that proliferation was abrogated in the presence of $100 \mu \mathrm{M}$ quercetin. Taken together, similar results proved the consistent effect of quercetin in NPC cells.

\section{Minor contribution of quercetin to apoptosis}

To determine if the quercetin-induced static impedance registered at $100 \mu \mathrm{M}$ was associated with apoptosis, HK1 cells exposed or not exposed to quercetin were incubated with FITC-conjugated annexin V and propidium iodide. Apoptotic cells were identified by flow cytometry (Figure 3). Treatment with $100 \mu \mathrm{M}$ quercetin for one day did not contribute markedly to cancer cell

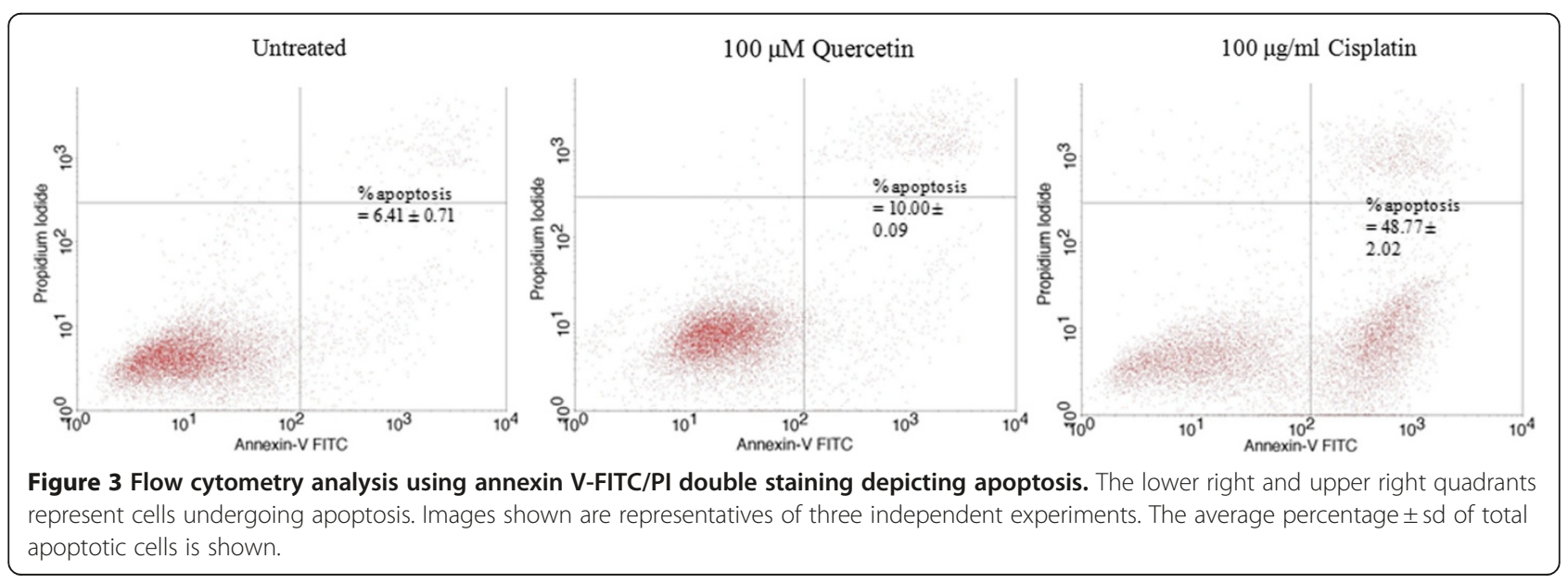




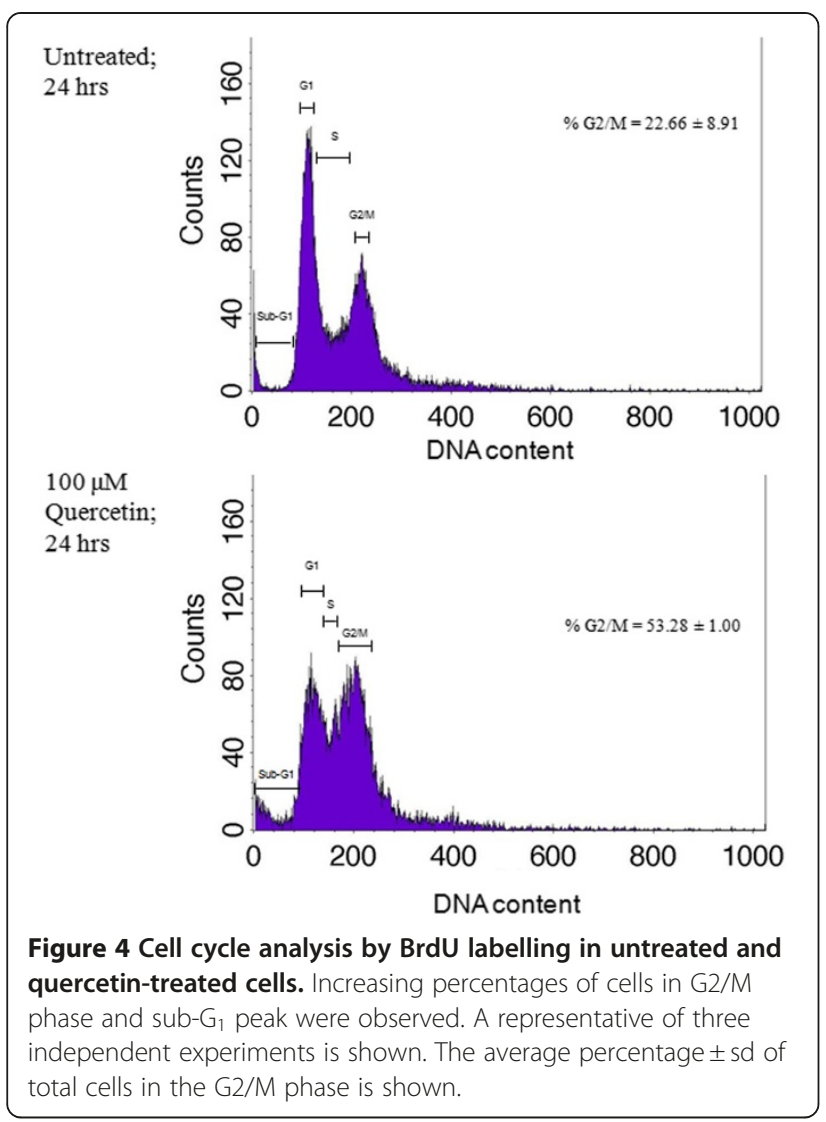

death. Hence, apoptosis is not the main mechanism of quercetin-induced growth inhibition. A comparison with cisplatin, a drug currently in use for NPC chemotherapy, is shown. Cisplatin clearly induced apoptosis in HK1 cells.

\section{Cell cycle arrest by quercetin}

To find out if exposure to quercetin affects cell cycle, DNA content was determined by flow cytometry. After 24 hours of $100 \mu \mathrm{M}$ quercetin exposure, there was a substantial increase of cells in G2/M phase in HK1 cells compared to untreated cells (Figure 4).

\section{Quercetin inhibits proliferation alone and displayed synergistic effects in combination with cisplatin}

Prior to assessing a two-drug combination effect on NPC cells, quercetin and cisplatin dose-response curves were generated for HK1 and C666-1. Cells in the solvent control group received DMSO only at the same concentration and volume as quercetin treatment and showed no influence on cell viability. Quercetin and cisplatin exerted their effects in a dose-dependent manner (Figure 5; cisplatin curves not shown). When NPC cells were grown in the presence or absence of quercetin and cisplatin, it was obvious that simultaneous treatment of a fixed combination ratio of quercetin and cisplatin exerted an effect greater than cisplatin alone (Figure 6). Using the
CalcuSyn software, we determined the combination index $(\mathrm{CI})$ to ascertain synergism $(\mathrm{CI}<1)$, antagonism $(\mathrm{CI}>1)$ or additive effect $(\mathrm{CI}=1)$. The $\mathrm{CI}$ values are tabulated (Table 1). The CI method, described in [15], revealed a synergistic cytotoxic effect in NPC cells (Figure 7).

\section{Discussion}

Many studies had reported the potential of the polyphenolic flavonoid, quercetin, as an anti-cancer agent. The interest in quercetin for therapeutics application is spurred by its ability to sensitize cells to the cytotoxic effects of platinum-containing drugs [16]. However, limited research is available on the role of quercetin in NPC and potentiation is seldom defined as additive or synergistic. Our work demonstrated that quercetin inhibited proliferation of NPC cells. Our data showed that quercetin synergizes with cisplatin in EBV-negative and EBVpositive NPC cells.

The limitation of cancer chemotherapy is cytotoxicity towards normal tissues and drug resistance. Intrinsic or acquired multidrug resistance (MDR) is a major impediment to successful chemotherapy. Quercetin showed growth inhibitory activity on both drug sensitive and MDR cells. Various findings with respect to modulating cancer MDR with quercetin had been comprehensively reviewed in [5]. The authors listed a number of studies demonstrating that natural products from plants such as

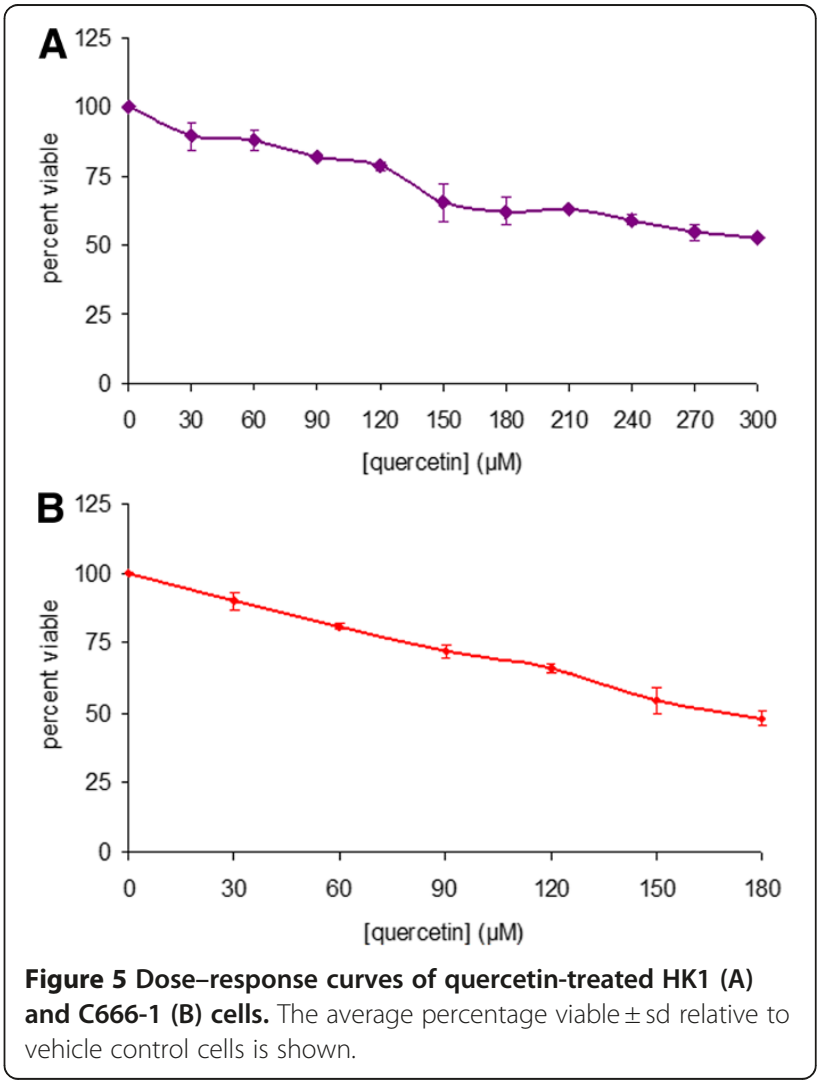




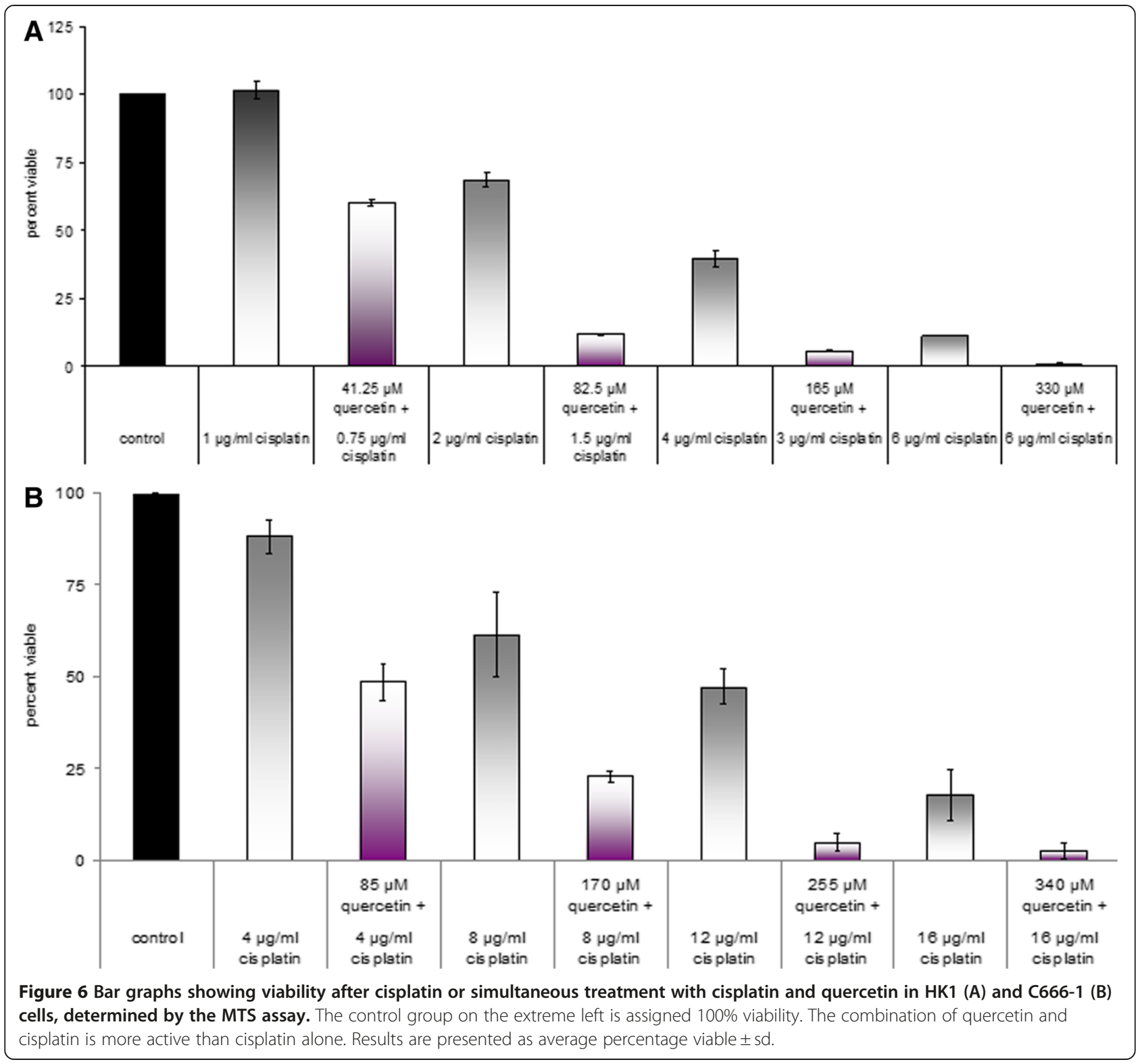

flavonoids are potential drugs to overcome MDR in many multidrug resistant cells. They also summarized a number of literatures on the effect of quercetin on compounds of which cellular accumulation, transport or bioavailability was increased in different model systems. In addition, quercetin at a non-cytotoxic concentration has enhanced the effect of chemotherapeutic drug on MDR cells. The candidacy of quercetin as a chemosensitizer for the $\mathrm{ABC}$ pump-proteins has been tested in a number of MDR tumour cell lines [5].

The richest sources of quercetin were onions $(347 \mathrm{mg} / \mathrm{kg})$, apples $(36 \mathrm{mg} / \mathrm{kg})$ and red wine $(11 \mathrm{mg} / \mathrm{kg})[17]$. The average intake of quercetin in the Netherlands was $16 \mathrm{mg} /$ day, with the main sources being tea, onions and apples [18]. The estimated daily dietary intake of quercetin in the U.S., Europe and Asia was 4-68 mg [5]. In ref. [19], it was stated that after the consumption of $1 \mathrm{~L}$ red wine, $1 \mathrm{~kg}$ broccoli, $1 \mathrm{~kg}$ onions or $1 \mathrm{~kg}$ apples, the estimated doses quercetin that will be reached are 19, 30,140 or $347 \mathrm{mg}$, respectively. From refs. [18, 20], by extrapolation, a serum concentration of $10 \mu \mathrm{M}$ might be attained from a daily dose of $1500 \mathrm{mg}$. Since this concentration required for anti-cancer activity $(>10 \mu \mathrm{M})$ is much higher than can be achieved by nutrition alone, a better source of quercetin are commercially available dietary quercetin tablets [19]. Repeated dietary intake of quercetin-containing foods would lead to accumulation of quercetin in the plasma [21]. Various studies on the pharmacokinetics analysis of quercetin in human plasma are available [22-24]. 
Table 1 Description of $\mathrm{Cl}$ values for each fraction of cells affected and the corresponding dose reduction index

\begin{tabular}{|c|c|c|c|c|c|}
\hline \multirow{2}{*}{$\begin{array}{l}\text { NPC } \\
\text { cell line }\end{array}$} & \multirow{2}{*}{$\begin{array}{l}\text { Fraction } \\
\text { affected }\end{array}$} & \multirow[t]{2}{*}{ CI } & \multirow[t]{2}{*}{ Description } & \multicolumn{2}{|c|}{ Dose reduction index (DRI) } \\
\hline & & & & Quercetin & Cisplatin \\
\hline \multirow[t]{4}{*}{ HK1 } & 0.395 & 0.474 & Synergism & 6.142 & 3.209 \\
\hline & 0.881 & 0.239 & $\begin{array}{l}\text { Strong } \\
\text { synergism }\end{array}$ & 128.972 & 4.319 \\
\hline & 0.943 & 0.338 & Synergism & 222.314 & 2.998 \\
\hline & 0.991 & 0.308 & Synergism & 2055.870 & 3.247 \\
\hline \multirow[t]{5}{*}{ C666-1 } & 0.171 & 0.981 & $\begin{array}{l}\text { Nearly } \\
\text { additive }\end{array}$ & 1.936 & 2.153 \\
\hline & 0.515 & 0.718 & $\begin{array}{l}\text { Moderate } \\
\text { synergism }\end{array}$ & 3.531 & 2.299 \\
\hline & 0.772 & 0.735 & $\begin{array}{l}\text { Moderate } \\
\text { synergism }\end{array}$ & 4.412 & 1.967 \\
\hline & 0.951 & 0.425 & Synergism & 11.690 & 2.944 \\
\hline & 0.974 & 0.402 & Synergism & 14.736 & 2.994 \\
\hline
\end{tabular}

DRI values $>1$ are beneficial and the greater the DRI values, the greater the dose reduction for a given therapeutic effect [15].

Cisplatin, often hampered by renal toxicity, preferentially accumulates in the cells of the proximal tubule. It was initially thought that a combination of quercetin and cisplatin might harm renal tubular cells and increased nephrotoxicity would limit the clinical value of a cisplatin-quercetin combination. It is of particular importance that in [25], quercetin reduced cisplatininduced nephrotoxicity in porcine LLC-PK 1 renal tubular epithelial cells. This is noteworthy of mention because in vitro $[9,26,27]$ and in vivo [13], quercetin was shown to enhance the anti-proliferative effects of cisplatin. Given that quercetin and cisplatin exhibited synergism, this combination could be a potential therapeutic application of clinical value in the management and treatment of human NPC. The beneficial DRI values listed in Table 1 indicate that quercetin may make it possible to lower cisplatin doses to below toxic levels, thereby possibly reducing toxicity whilst maintaining or improving efficacy. Quercetin, by itself (Figures 3 and 5), appears to confer little toxicity, in agreement with [13] which stated that quercetin is a weakly toxic drug, and seemed more likely to confer cytostatic effects (Figure 4).

\section{Conclusion}

In our study, quercetin consistently inhibited proliferation of NPC cells. The effect of quercetin was associated with cell cycle arrest in the G2/M phase. In addition, quercetin synergized with cisplatin in causing antiproliferative effects in NPC cells. This study suggests that the potential of quercetin as a chemotherapeutic agent in human NPC should be explored further.

\section{Methods}

Cell lines and culture

$\mathrm{HK} 1$, an EBV-negative NPC cell line acquired from George Tsao and co-workers, was maintained in the exponential growth phase in RPMI 1640 medium (GIBCO, Invitrogen, Carlsbad, CA) supplemented with $10 \%$ heatinactivated foetal calf serum (FCS; GIBCO), $10 \mathrm{U}$ of penicillin per $\mathrm{ml}(\mathrm{GIBCO})$, and $10 \mu \mathrm{g}$ streptomycin per $\mathrm{ml}(\mathrm{GIBCO})$ at $37{ }^{\circ} \mathrm{C}$ in a $5 \% \mathrm{CO}_{2}$ humidified atmosphere. C666-1, an EBV-positive NPC cell line supplied by Kwok-Wai Lo, was maintained similarly but FCS concentration was increased to $15 \%$. The establishment and characterization of HK1 was described in [28]; whereas that of C666-1 in [29]. The identity of HK1 and C666-1 were validated by DNA fingerprinting using AmpFISTR Identifiler ${ }^{\circledR}$ PCR amplification kit (Applied Biosystems, Foster City, CA). The short tandem repeat profiles were consistent with the original NPC cells [30]. Tests for detection of mycoplasma using $e$-myco ${ }^{\text {tw }}$ Mycoplasma PCR Detection Kit (iNtRON Biotechnology, INC., Korea)

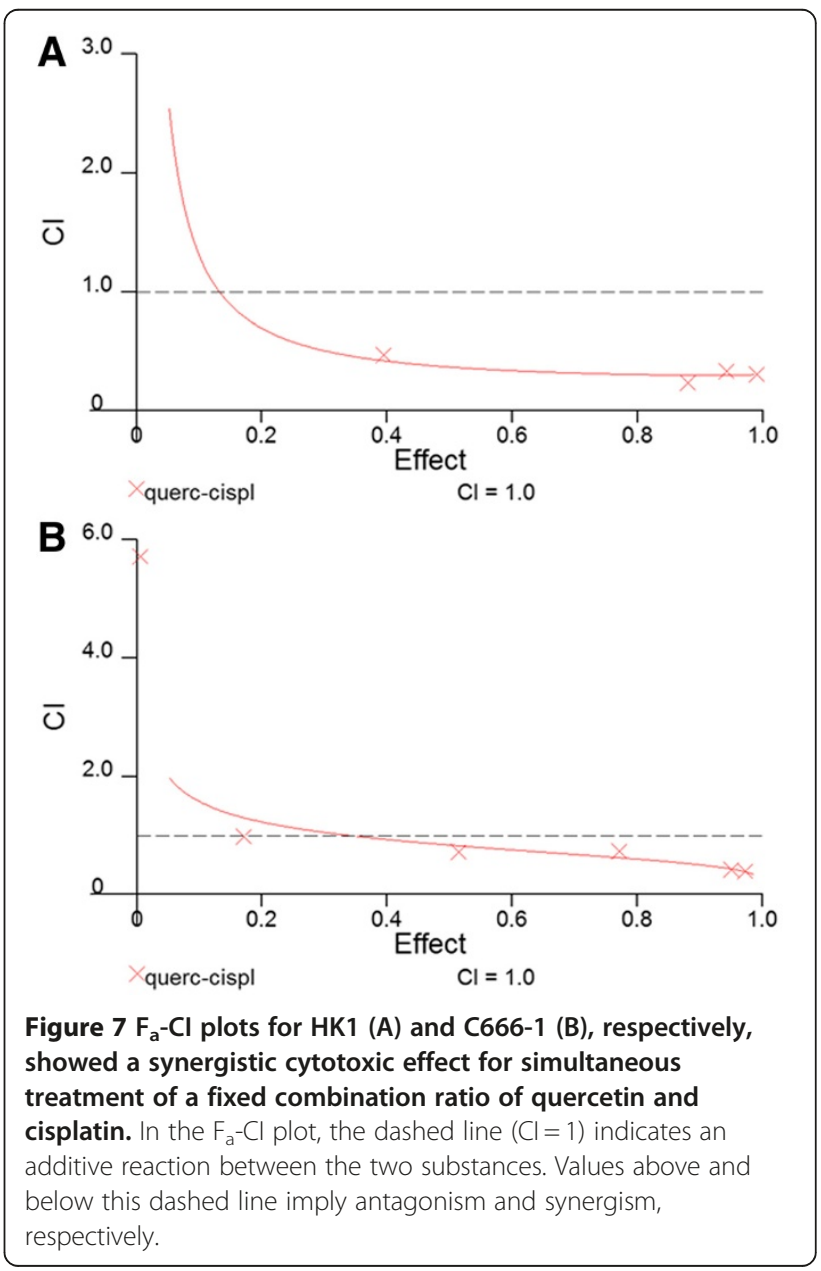


were conducted routinely and contamination-free cells were used throughout this study.

\section{xCELLigence cell proliferation assay}

HK1 cells were seeded at a density of 5000 cells/well into three E-Plate 16 (ACEA Biosciences, Inc., San Diego, CA) containing $100 \mu \mathrm{l}$ medium per well supplemented with $10 \%$ FCS. When the cells have entered logarithmic phase, $1 \mathrm{mM}$ quercetin $\left(\mathrm{C}_{15} \mathrm{H}_{10} \mathrm{O}_{7} \cdot \mathrm{xH}_{2} \mathrm{O}\right.$, molecular weight $=302.24$ anhydrous basis, purity $\geq 95 \%$ ) from Sigma dissolved in dimethyl sulfoxide (DMSO) (Sigma) was prepared. Old culture medium was aspirated and replaced with culture medium containing quercetin to yield a final concentration of $1-100 \mu \mathrm{M}$. Final DMSO concentration in the cell culture did not exceed $0.5 \%$. Cells were monitored for approximately 60 hours at $37{ }^{\circ} \mathrm{C}$ in a $5 \% \mathrm{CO}_{2}$ atmosphere, with one change of freshly-prepared medium and quercetin at the appropriate concentrations at 24 hours post-treatment. Dynamic monitoring of the growth inhibition pattern was determined by the impedance-based xCELLigence system (Roche Applied Science, Germany). The cell index was derived from measured cell-electrode impedance that correlates with number of cells, viability, and/ or cytotoxicity. Vehicle control cultures received DMSO alone. For C666-1, 15000 cells/well were seeded and medium was supplemented with 15\% FCS.

\section{Western blotting}

$1.2 \times 10^{6}$ cells were seeded in $10-\mathrm{cm}$ culture dishes and allowed to enter logarithmic phase prior to treatment, after which the cells were cultured for an additional 24 hours in medium without or with $100 \mu \mathrm{M}$ quercetin. Cells were lysed in 1X RIPA lysis buffer and then boiled for 10 minutes. The quantity of protein in the cell lysate was determined by protein assay (BioRad Laboratory, Hercules, CA). $10 \mu \mathrm{g}$ of protein was resolved in NuPAGE ${ }^{\circledR}$ Novex ${ }^{\circledR}$ Bis-Tris Mini Gels (Invitrogen) and electrotransferred to polyvinylidene fluoride membranes (Millipore, Bedford, MA). The membranes were blocked with $5 \%$ skimmed milk and incubated overnight in primary antibodies diluted in 5\% skimmed milk. Primary antibodies used include anti-FASN (Abcam, Cambridge, UK), anti-beta-actin (Santa Cruz Biotechnology, Inc., CA, USA) and monoclonal mouse anti-human Ki67 antigen (DakoCytomation Glostrup, Denmark). The secondary antibody reaction was carried out with antimouse or anti-rabbit horseradish peroxidase-conjugated IgG (Promega). Western Lighting ${ }^{\circledR}$ Plus ECL substrate (PerkinElmer, Waltham, MA) and autoradiography were employed for visualization of protein expression. Densitometry analysis of X-ray films was performed on Alpha Imager System (Alpha Innotech/ProteinSimple, Santa Clara, CA, USA) using Alpha View software.

\section{Apoptosis analysis assay}

$1.2 \times 10^{6} \mathrm{HK} 1$ cells were seeded in 10-cm culture dishes and were allowed to adhere overnight. Following this, cells were treated either with $100 \mu \mathrm{M}$ quercetin, $100 \mu \mathrm{g} / \mathrm{ml}$ cisplatin, or DMSO vehicle (as control). All culture dishes were re-incubated for another 24 hours. Apoptosis was determined on a FACSCalibur flow cytometer (BD Biosciences, San Jose, CA), using the BD Pharmingen FITC Annexin V apoptosis detection kit (San Diego, CA), according to the manufacturer's protocol provided.

\section{Cell cycle analysis assay}

$1.2 \times 10^{6} \mathrm{HK} 1$ cells were seeded in 10-cm culture dishes and left overnight; after which treated cells received $100 \mu \mathrm{M}$ of quercetin for 24 hours whereas untreated control cultures received DMSO alone. Cultured cells were labelled with $10 \mu \mathrm{M}$ BrdU in medium for 17 hours before they were harvested. Cell cycle distribution was determined on a FACSCalibur flow cytometer, using the BrdU incorporation method with the BD Pharmingen FITC BrdU Flow Kit (San Diego, CA).

\section{MTS [3-(4,5-dimethylthiazol-2-yl)-5-(3- carboxymethoxyphenyl)-2-(4-sulfophenyl)-2 $\mathrm{H}$-tetrazolium] assay}

5000 HK1 or 15000 C666-1 cells/well were seeded into 96-well microtiter plates then incubated until logarithmic phase was achieved prior to treatment. Then, old medium was aspirated and the cells were incubated in $100 \mu \mathrm{l}$ medium containing various concentrations of quercetin or cisplatin for 3 days at $37{ }^{\circ} \mathrm{C}$ in a $5 \% \mathrm{CO}_{2}$ atmosphere. The number of viable cells at the end of the incubation period was measured using the CellTiter $96^{\circledR}$ $\mathrm{AQ}_{\text {ueous }}$ One Solution Cell Proliferation (MTS) assay (Promega, Madison, WI), according to the protocol provided by the manufacturer. Absorbance at $490 \mathrm{~nm}$ was read using the EnVision multilabel plate reader (PerkinElmer, Waltham, MA). Non-specific absorbance was measured at $630 \mathrm{~nm}$. Wells containing the appropriate medium but without cells served as blank. Cell viability was calculated as percentage compared to control cells, which were arbitrarily assigned $100 \%$ viable and the growth curve was plotted. All experiments were performed in triplicates and values were reported as mean $\pm \mathrm{sd}$.

For combined drug analysis, a fixed ratio combination of quercetin and cisplatin was evaluated. The doses of quercetin and cisplatin were chosen based on $\mathrm{IC}_{50}$ values, defined as the concentration that inhibited 50\% cell growth relative to control cells. For drug combination studies, plates were assigned for single-drug only and two-drug and the experiments were carried out simultaneously to rule out different experimental conditions [15]. Following drug addition, the 96-well microtiter 
plates were incubated for 3 days and the MTS assay was carried out to determine percent viability.

\section{Combined drug analysis}

Drug interaction was determined by the combinationindex (CI) method described in [15]. Dose-response curves, dose-effect analysis and $\mathrm{CI}$ for the combination treatment group were generated using CalcuSyn 2 software (Biosoft, Cambridge, UK). A CI of $>1$ implies antagonism, $\mathrm{CI}=1$ is additivity and $\mathrm{CI}<1$ is synergy.

\section{Abbreviations}

BrdU: Bromodeoxyuridine; Cl: Combination index; DMSO: Dimethyl sulfoxide; DNA: Deoxyribonucleic acid; DRI: Dose-reduction index; EBV: Epstein-Barr virus; ECL: Enhanced chemiluminescence; FASN: Fatty acid synthase; FCS: Foetal calf serum; MDR: Multidrug resistance; MTS: [3-(4,5dimethylthiazol-2-yl)-5-(3-carboxymethoxyphenyl)-2-(4-sulfophenyl)-2 Htetrazolium]; NPC: Nasopharyngeal carcinoma; PCR: Polymerase chain reaction.

\section{Competing interests}

The authors declare that they have no competing interests.

\section{Acknowledgements}

We thank the Director General of Health Malaysia for his permission to publish this article and the Director of the Institute for Medical Research for her support. We thank George Tsao (University of Hong Kong) and Kwok-Wai Lo (Chinese University of Hong Kong) for kindly providing HK1 and C666-1. cells, respectively. This work has been supported by the Ministry of Health Malaysia.

\section{Authors' contributions}

Conceived and designed the experiments: MD, Acquisition of data: MD, Analyzed and interpreted the data: MD, ASBK, MA. Wrote the paper: MD, Critical and intellectual revision of the article contents: ASBK, MA. All authors read and approved the final manuscript.

\section{Received: 29 May 2012 Accepted: 9 July 2012}

Published: 18 July 2012

\section{References}

1. Wei WI, Sham JS: Nasopharyngeal carcinoma. Lancet 2005, 365:2041-2054.

2. Chou J, Lin YC, Kim J, You L, Xu Z, He B, Jablons DM: Nasopharyngeal carcinoma-review of the molecular mechanisms of tumorigenesis. Head Neck 2008, 30:946-963.

3. Tao Q, Chan AT: Nasopharyngeal carcinoma: molecular pathogenesis and therapeutic developments. Expert Rev Mol Med 2007, 9:1-24.

4. Spano JP, Busson P, Atlan D, Bourhis J, Pignon JP, Esteban C, Armand JP: Nasopharyngeal carcinomas: an update. Eur J Cancer 2003, 39:2121-2135.

5. Chen C, Zhou J, Ji C: Quercetin: A potential drug to reverse multidrug resistance. Life Sci 2010, 87:333-338.

6. Murakami A, Ashida H, Terao J: Multitargeted cancer prevention by quercetin. Cancer Lett 2008, 269:315-325.

7. Brusselmans K, Vrolix R, Verhoeven G, Swinnen JV: Induction of cancer cel apoptosis by flavonoids is associated with their ability to inhibit fatty acid synthase activity. J Biol Chem 2005, 280:5636-5645.

8. Zhang F, Cui Y, Cao P: Effect of quercetin on proliferation and apoptosis of human nasopharyngeal carcinoma HEN1 cells. J Huazhong Univ Sci Technolog Med Sci 2008, 28:369-372.

9. Sharma H, Sen S, Singh N: Molecular pathways in the chemosensitization of cisplatin by quercetin in human and neck cancer. Cancer Biology \& Therapy 2005, 4:949-955.

10. Yoshida M, Yamamoto M, Nikaido T: Quercetin arrests human leukemic T-cells in late G1 phase of the cell cycle. Cancer Res 1992, 52:6676-6681.

11. Yoshida M, Sakai T, Hosokawa N, Marui N, Matsumoto K, Fujioka A, Nishino $H$, Aoike A: The effect of quercetin on cell cycle progression and growth of human gastric cancer cells. FEBS Lett 1990, 260:10-13.
12. Dihal AA, Woutersen RA, van Ommen B, Rietjens IMCM, Stierum RH: Modulatory effects of quercetin on proliferation and differentiation of the human colorectal cell line Caco-2. Cancer Lett 2006, 238:248-259.

13. Hofmann J, Fiebig HH, Winterhalter BR, Berger DP, Grunicke H: Enhancement of the antiproliferative activity of cis-diamminedichloroplatinum(II) by quercetin. Int I Cancer 1990, 45:536-539.

14. Menendez JA, Lupu R: Fatty acid synthase and the lipogenic phenotype in cancer pathogenesis. Nat Rev Cancer 2007, 7:763-777.

15. Chou T-C: Theoretical basis, experimental design, and computerized simulation of synergism and antagonism in drug combination studies. Pharmacol Rev 2006, 58:621-681.

16. Cross HJ, Tilby M, Chipman K, Ferry DR, Gescher A: Effect of quercetin on the genotoxic potential of cisplatin. Int J Cancer 1996, 66:404-408.

17. Ferry DR, Smith A, Malkhandi J, Fyfe DW, De Takats PG, Anderson D, Baker J, Kerr DJ: Phase I clinical trial of the flavonoid quercetin: pharmacokinetics and evidence for in vivo tyrosine kinase inhibition. Clin Cancer Res 1996, 2:659-668.

18. Hollman PCH, van Trijp JMP, Mengelers MJB, de Vries JHM, Katan MB: Bioavailability of the dietary antioxidant flavonol quercetin in man. Cancer Lett 1997, 114:139-140.

19. Zhou W, Kallifatidis G, Baumann B, Rausch V, Mattern J, Gladkich J, Giese N, Moldenhauer G, Wirth T, Büchler MW, et al: Dietary polyphenol quercetin targets pancreatic cancer stem cells. Int J Oncol 2010, 37:551-561.

20. Lamson DW, Brignall MS: Antioxidants and Cancer III: Quercetin. Alternative Medicine Review 2000, 5:196-208.

21. Hollman PCH, van Trijp JMP, Buysman MNCP, van der Gaag MS, Mengelers MJB, de Vries JHM, Katan MB: Relative bioavailability of the antioxidant flavonoid quercetin from various foods in man. FEBS Lett 1997 , 418:152-156.

22. Lee J, Mitchell AE: Pharmacokinetics of quercetin absorption from apples and onions in healthy humans. J Agric Food Chem 2012, 60:3874-3881.

23. Graefe EU, Wittig J, Mueller S, Riethling AK, Uehleke B, Drewelow B, Pforte $H$, Jacobasch G, Derendorf H, Veit M: Pharmacokinetics and bioavailability of quercetin glycosides in humans. J Clin Pharmacol 2001, 41:492-499.

24. Erlund I, Kosonen T, Alfthan G, Mäenpää J, Perttunen K, Kenraali J, Parantainen J, Aro A: Pharmacokinetics of quercetin from quercetin aglycone and rutin in healthy volunteers. Eur I Clin Pharmacol 2000, 56:545-553.

25. Kuhlmann MK, Horsch E, Burkhardt G, Wagner M, Köhler H: Reduction of cisplatin toxicity in cultured renal tubular cells by the bioflavonoid quercetin. Arch Toxicol 1998, 72:536-540.

26. Jakubowicz-Gil J, Paduch R, Piersiak T, Glowniak K, Gawron A, KandeferSzerszen M: The effect of quercetin on pro-apoptotic activity of cisplatin in HeLa cells. Biochem Pharmacol 2005, 69:1343-1350.

27. Scambia G, Ranelletti FO, Benedetti Panici P, Piantelli M, Bonanno G, De Vincenzo R, Ferrandina G, Maggiano N, Capelli A, Mancuso S: Inhibitory effect of quercetin on primary ovarian and endometrial cancers and synergistic activity with cis-diamminedichloroplatinum(II). Gynecol Oncol 1992, 45:13-19.

28. Huang DP, Ho JH, Poon YF, Chew EC, Saw D, Lui M, Li CL, Mak LS, Lai SH, Lau WH: Establishment of a cell line (NPC/HK1) from a differentiated squamous carcinoma of the nasopharynx. Int J Cancer 1980, 26:127-132.

29. Cheung ST, Huang DP, Hui AB, Lo KW, Ko CW, Tsang YS, Wong N, Whitney BM, Lee JC: Nasopharyngeal carcinoma cell line (C666-1) consistently harbouring Epstein-Barr virus. Int J Cancer 1999, 83:121-126.

30. Chan SY-Y, Choy K-W, Tsao S-W, Tao Q, Tang T, Chung GT-Y, Lo K-W: Authentication of nasopharyngeal carcinoma tumor lines. Int J Cancer 2008, 122:2169-2171.

doi:10.1186/1475-2867-12-34

Cite this article as: Daker et al: Quercetin-induced inhibition and synergistic activity with cisplatin - a chemotherapeutic strategy for nasopharyngeal carcinoma cells. Cancer Cell International 2012 12:34. 